\title{
Four new species of Acanthobothrium van Beneden, 1850 (Cestoda: Onchoproteocephalidea) from the guitarfish, Rhynchobatus cf. djiddensis (Elasmobranchii: Rhynchobatidae), from the Persian Gulf and Gulf of Oman
}

\author{
Loghman Maleki ${ }^{1,2}$, Masoumeh Malek $^{1}$ and Harry W. Palm ${ }^{3}$ \\ ${ }^{1}$ School of Biology and Center of Excellence in Phylogeny of Living Organisms, College of Science, University of Tehran, Iran; \\ ${ }^{2}$ Department of Biological Sciences and Biotechnology, Faculty of Science, University of Kurdistan, Sanandaj, Iran; \\ ${ }^{3}$ Aquaculture and Sea-Ranching, Faculty of Agricultural and Environmental Sciences, University Rostock, Rostock, Germany
}

\begin{abstract}
Four new species of Acanthobothrium van Beneden, 1850 are described from guitarfish, Rhynchobatus cf. djiddensis (Forsskål), collected from the Gulf of Oman and Persian Gulf. Acanthobothrium janineae sp. n., a category 1 species, differs from all congeners in category 1 by having a long vagina extending into the vas deferens and different, proglottid and testis number except Acanthobothrium hypermekkolpos Fyler et Caira, 2010. Acanthobothrium fylerae sp. n., a category 1 species, can be differentiated by a combination of characters including the total length, proglottid and testis number, cirrus sac shape, and the length of the vagina and ovarian lobes. Both new species are similar to A. hypermekkolpos reported from Rhynchobatus laevis (Bloch et Schneider) from Australia in their scolex proper length, hook size and muscular pad, respectively. Acanthobothrium asrinae sp. n., a category 1 species, differs from other category 1 species by the shape of its hooks and the position of the tubercle at the mid-length of the axial prongs; in this respect it resembles $A$. bartonae Campbell et Beveridge, 2002 reported from Australia. Acanthobothrium jamesi sp. n. is among six category 1 species with post-ovarian testes. It differs from these species by total length, proglottid and testis number and the extension of the ovarian lobes. Although it is thought that $R$. djiddensis occurs in the region, the identities of the hosts of the newly described Acanthobothrium species await verification. There are two forms of host in the region and were designated as $R$. cf. djiddensis 1 and $R$. cf. djiddensis 2. More taxonomic work and the use of molecular techniques are needed to resolve the true identity of the host species.
\end{abstract}

Keywords: new species, Acanthobothrium, Guitarfish, parasites, Onchobothriidae, sharks, Iran

Acanthobothrium van Beneden, 1850 is one of the most widespread and species-rich cestode genera with species that parasitise elasmobranchs, including sharks and batoids. To date, 178 species have been described and new species are described almost each year (Maleki et al. 2013). The majority of Acanthobothrium species has been reported from stingrays (see Campbell and Beveridge 2002, Ivanov 2005, Fyler 2011) and only 10 records exist from Rhynchobatus Muller et Henle. Subhapradha (1955) described A. rhynchobatidis rotundum Subhapradha, 1955 and $A$. rhynchobatidis elongatum Subhapradha, 1955 from R. djiddensis (Forsskål) off India, both synonymised with A. rhynchobatidis Campbell et Beveridge, 2002 by Campbell and Beveridge (2002), and Yang and Lin (1994) described A. xiamense Yang et Lin, 1994 from $R$. djiddensis in China. Campbell and Beveridge (2002) described A. bartonae Campbell et Beveridge, 2002, A. gibsoni Campbell et Beveridge, 2002, A. lasti Campbell et Beveridge, 2002, and redescribed A. rhynchobatidis Subhapradha, 1955 from what they reported as $R$. djiddensis (Subhapradha, 1955) from Australia.

Most recently, Fyler and Caira (2010) added A. bobconniorum Fyler et Caira, 2010, A. hypermekkolpos Fyler et Caira, 2010, A. jeanneae Fyler et Caira, 2010 and A. matttaylori Fyler et Caira, 2010 from Rhynchobatus laevis (Bloch et Schneider) from Australia.

The genus Rhynchobatus includes six species in the Indo-Pacific region and a single species in Western Africa. Campagno and Last $(2008,2010)$ recognised seven species, including $R$. djiddensis (Western Indian Ocean), $R$. laevis (Indo-Pacific), R. luebberti Ehrenbaum (Eastern Pacific), R. australiae Whitley (Eastern Indian Ocean), $R$. palpebratus Compagno et Last (Indo-Malay Archipelago), $R$. springeri Campagno et Last (Western Pacific), Rhynchobatus sp. 1. of Campagno and Last (1999) (Singapore and Java) and Rhynchobatus sp. 2. of Campagno and Last (1999) (Western Pacific). Consequently, only $R$. djiddensis and $R$. laevis have been reported from the Western 
Indian Ocean, including the waters off India, the Arabian Sea, Red Sea, Persian Gulf and Gulf of Oman. Randall (1995), Carpenter et al. (1997) and Bonfil and Abdallah (2004) recognised $R$. djiddensis as the only species in the Persian Gulf and Gulf of Oman.

During a study on cestode parasites from the Persian Gulf and Gulf of Oman, we encountered specimens of different orders such as the Lecanicephalidea, Rhinebothriidea, Tetraphyllidea and Trypanorhyncha. Haseli et al. (2010) reported four species of Trypanorhyncha from $R$. cf. djiddensis from the Persian Gulf, and Maleki et al. (2013) reported the first two species of Acanthobothrium from Pastinachus cf. sephen (Forsskål) from the Persian Gulf and Gulf of Oman. Out of 23 Acanthobothrium species from the Western Indian Ocean, only a single species has been reported from $R$. djiddensis to date. We herewith describe four new species of Acanthobothrium from $R$. cf. djiddensis.

\section{MATERIALS AND METHODS}

Since there is confusion regarding the identity of Rhychobatus in the study region, and two distinct colour patterns were seen in the area (Figs. 44, 45), we have used the designations $R$. cf. djiddensis 1 and $R$. cf. djiddensis 2 for the hosts. Six specimens of Rhynchobatus cf. djiddensis 1 and two specimens of Rhynchobatus cf. djiddensis 2 were collected by bottom trawl in August 2010 from the Chabahar coast $\left(25^{\circ} 11^{\prime} \mathrm{N}\right.$; $\left.60^{\circ} 33^{\prime} \mathrm{E}-25^{\circ} 25^{\prime} \mathrm{N} ; 57^{\circ} 43^{\prime} \mathrm{E}\right)$ and Bandar Abbas $\left(26^{\circ} 15^{\prime} \mathrm{N} ; 53^{\circ} 02^{\prime} \mathrm{E}-27^{\circ} 04^{\prime} \mathrm{N} ; 57^{\circ} 01^{\prime} \mathrm{E}\right)$, off the Iranian coast of the Gulf of Oman and Persian Gulf. The total length $(54-135 \mathrm{~cm})$, disk width $(19-48 \mathrm{~cm})$ and sex of each elasmobranch specimen were recorded. Data about these specimens are available in the Global Cestode Database under URL: www. elasmobranchs.tapewormdb.uconn.edu. The collection code for specimens within the website is MM and the specimen collection numbers are MM-653, MM-693, MM-699, MM-743, MM-1096 and MM-1126. The spiral intestines were removed and opened with a longitudinal incision, placed in $10 \%$ formalin buffered with seawater and vigorously shaken for around one min, and stored in this fixative for two weeks. Tetraphyllidean cestodes were removed and stored in $70 \%$ ethanol.

Morphological data were obtained from whole mounts and specimens prepared for scanning electron microscopy (SEM). Worms for light microscopy were hydrated in an ethanol series, stained in Delafield's hematoxylin, dehydrated in a graded ethanol series, cleared in methyl salicylate, and mounted onto glass slides in Canada balsam. A total of five scolices of four Acanthobothrium species were prepared for scanning electron microscopy (SEM), their strobilae were processed as whole mounts for vouchers. Specimens were dehydrated in an ethanol series, transferred to $100 \%$ acetone, dried in a Critical Point Dryer BALTIC SCD004 and mounted onto carbon tape on aluminum stubs. Specimens were coated with $15 \mathrm{~nm}$ gold and examined with a SEM model Zeiss DSM 960A.

Illustrations were made with the help of a drawing tube. Images were taken with a digital camera Olympus and Cellsens Dimension software attached to an Olympus BX53 light microscope. All measurements are given in micrometers unless otherwise indicated. The range is given, followed by mean, standard deviation, number of measured worms and number of measurements taken in parentheses.

To facilitate comparison with the 170+ Acanthobothrium species, the categorisation system by Ghoshroy and Caira (2001) was used. The new specimens were compared with type material available at the Lawrence R. Penner Parasitology Collection, Department of Ecology and Evolutionary Biology, University of Connecticut, Storrs, Connecticut. Hook dimensions were measured according to Euzet (1959), modified by Ghoshroy and Caira (2001), and measurements follow Campbell and Beveridge (2002). Hook terminology for medial and lateral hooks follows Ghoshroy and Caira (2001) as follows: base length (A, A'), axial hook length (B, B'), abaxial hook length (C, C'), total hook length or axial total hook length (D, D'), and two additional measurements according to Campbell and Beveridge (2002): abaxial total hook length (E, E') and interprong distance between the axial and abaxial tips of each hook (W, W'). Microthrix terminology follows Chervy (2009).

Additional museum abbreviations used are as follows: ZMB, the Natural History Museum Berlin, Germany, and ZUTC, Collection of the Zoological Museum, University of Tehran, Tehran, Iran.

\section{RESULTS}

\section{Acanthobothrium janineae sp. n. Figs. 1-5, 11-16}

ZooBank number for species:

urn:1sid:zoobank.org:act:1A9A81B9-67F6-41E6-816F-63710BDC976D

Description (based on whole mounts of 11 mature worms, 2 scolices examined with SEM and the whole mounts of their vouchers). Worms $2.5-3.8 \mathrm{~mm}$ $(2.9 \pm 0.4 \mathrm{~mm} ; 11 ; 11)$ long; greatest width at level of terminal proglottid; $7-10(9 \pm 1 ; 11 ; 11)$ proglottids per worm; euapolytic. Scolex consisting of scolex proper and conspicuous cephalic peduncle. Scolex proper with four bothridia, 201-285 $(250 \pm 27 ; 11 ; 11)$ long. Bothridia free posteriorly, $306-373(334 \pm 18 ; 11 ; 11)$ long by $87-105$ $(98 \pm 5 ; 15 ; 11)$ wide; each with three loculi separated by two transverse septa, and a specialised anterior region in form of a muscular pad; muscular pad 64-90 (78 \pm 9 ; 11; 14) long by $77-105(93 \pm 7 ; 11 ; 14)$ wide, triangular in shape, bearing of apical sucker and one pair of hooks at posterior margin. Apical sucker 26-43 $(35 \pm 6 ; 11 ; 13)$ long by $31-54(40.4 \pm 7 ; 11 ; 13)$ wide; anterior loculus $127-162$ (140 $\pm 10 ; 11 ; 11)$ long; middle loculus 44-66 (58 \pm 7 ; 11; 11) long; posterior loculus 46-74 (69 \pm 9 ; 11; 11) long; ratio of locular length (anterior : middle : posterior) 1 : 0.29-0.56:0.34-0.56 ( $1: 0.42 \pm 0.42: 0.06 \pm 0.06 ; 11$; $14)$; maximum width of scolex, 175-208 $(190 \pm 9 ; 11 ; 11)$, at level of middle loculus. Velum present between medial margins of adjacent bothridia at level of posterior loculus.

Hooks bipronged, hollow, with tubercle on proximal surface of axial prongs; internal channels of axial and abaxial prongs continuous, lateral and medial hooks equal in size; axial prongs slightly longer than abaxial prongs; axial prong of medial hook slightly longer than axial prong of lateral hook. Lateral hook measurements: A 40-46 $(43 \pm 2 ; 11 ; 16)$, B $61-77(68 \pm 5 ; 11 ; 16)$, C 46-65 (57 \pm 5 ; 

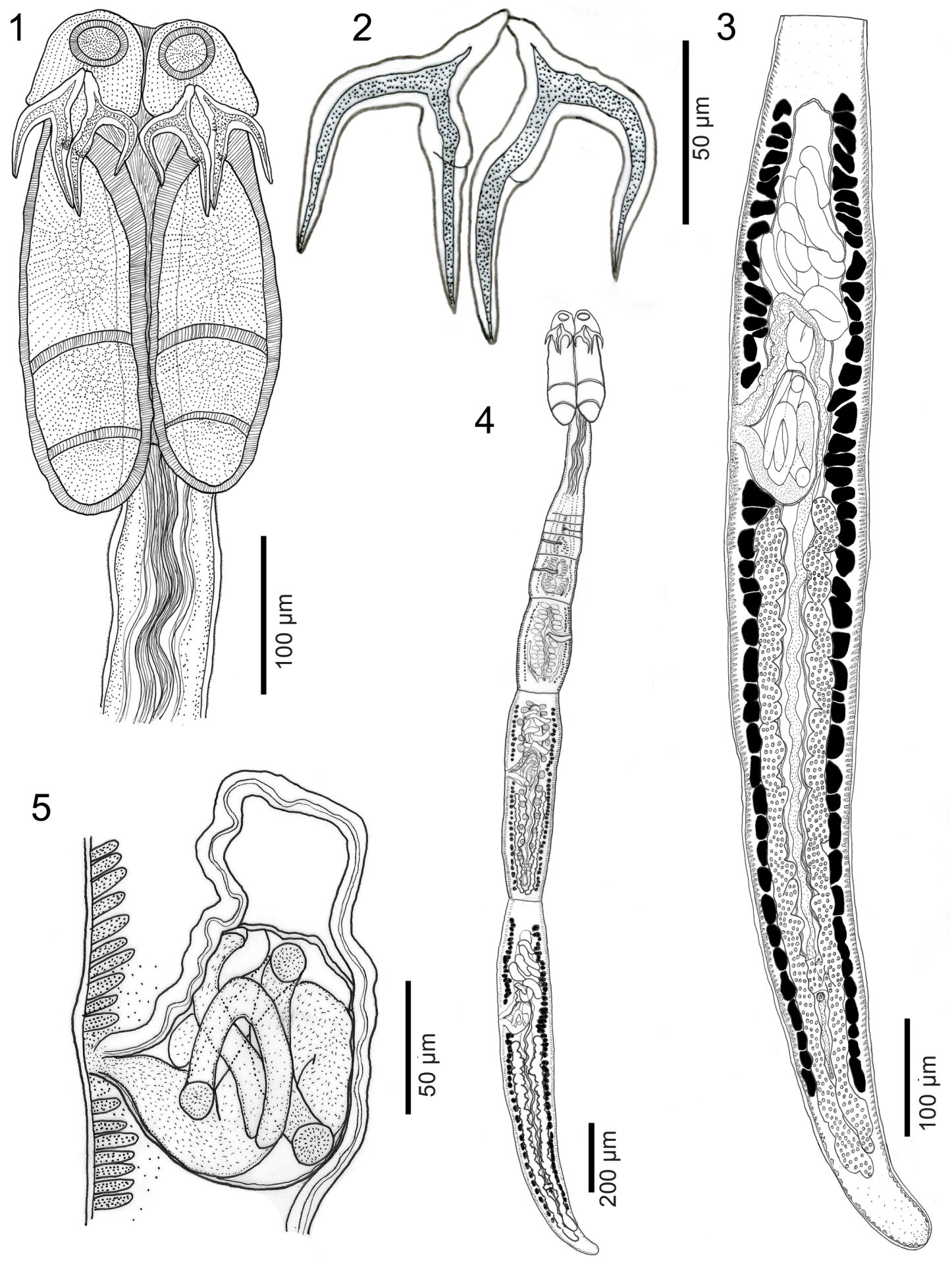

$\frac{\frac{5}{2}}{ㅇ ㅇ ㅁ ~}$

Figs. 1-5. Acanthobothrium janineae sp. n. from Rhynchobatus cf. djiddensis 1. Fig. 1. Scolex. Fig. 2. Hooks. Fig. 3. Terminal mature proglottid. Fig. 4. Whole worm. Fig. 5. Terminal genitalia.

$11 ; 16)$, D 93-112 (103 $\pm 6 ; 11 ; 16)$, E 90-107 (100 \pm 5 ; $11 ; 16)$, W 36-53 (43 $\pm 5,11 ; 16)$. Medial hook measurements: A' 35-46 (39 $\pm 3 ; 11 ; 16)$, B' 65-84 (76 $\pm 5 ; 11$; 16), C' 39-66 (51 $\pm 7 ; 11 ; 16)$, D' 97-115 (108 $\pm 5,11$; 16), E' 77-100 (90 $\pm 6 ; 11 ; 16), W^{\prime} 32-53$ (41 $\pm 6 ; 11$; 16). Bases of lateral and medial hooks approximately equal in length; embedded in muscular pad. Cephalic peduncle $198-392(266 \pm 61 ; 11)$ long by $64-92(77 \pm 9 ; 11)$ wide at mid-level.
Apical pad surface (Fig. 13) and distal bothridial surfaces (Fig. 15) covered with papilliform filitriches. Proximal bothridial surfaces (Fig. 14) covered with gladiate spinitriches interspersed with capilliform filitriches. Cephalic peduncle (Fig. 16) covered with densely arranged gladiate spinitriches interspersed with capilliform filitriches.

Proglottids acraspedote, protandrous. Immature proglottids $4-7(5.5 \pm 0.8 ; 11 ; 11)$ in number; mature proglottids $2-4(2.8 \pm 0.7 ; 11 ; 11)$ in number. Terminal mature proglot- 
tid 797-1435 (1088 $\pm 150 ; 13 ; 13)$ long by $109-228$ $(170 \pm 34 ; 13 ; 13)$ wide, length : width ratio $3.5-9.3: 1$ $(6.3 \pm 1.5 ; 13 ; 13)$. Gravid proglottids not observed. Genital pores lateral, alternating irregularly, 63-79\% (68 $\pm 4 \%$; $13 ; 13)$ of proglottid length from posterior end. Testes irregularly oval in frontal view, $14-35(22 \pm 5 ; 13 ; 18)$ long by $27-51(38 \pm 8 ; 13 ; 18)$ wide, arranged in two regular columns anterior to ovarian isthmus, 22-29 (24 \pm 3 ; 13; $14)$ in total number, $4-7(5.9 \pm 0.8 ; 13 ; 13)$ in postporal field, no testes posterior to ovarian isthmus, atrophied in mature proglottids. Cirrus sac J-shaped, extending anteriorly, 71-187 (129 $\pm 34 ; 13 ; 13)$ long by $85-155(112 \pm 34$; 13 ; 13) wide, containing long coiled cirrus; cirrus expanded at base; most of cirrus length covered with spinitriches. Extensive vas deferens in anterior part of mature proglottid.

Vagina thick-walled, sinuous, extending from ootype along midline of proglottid to anterior margin of cirrus sac, extending well into coils of vas deferens, then bent posteriorly to anterior margin of cirrus sac to common genital atrium; vaginal sphincter absent; seminal receptacle not seen. Ovary occupying posterior half of proglottid, symmetrical, $472-799(596 \pm 82 ; 13 ; 13)$ long, maximum width 70-120 $(88 \pm 16 ; 13 ; 13)$, H-shaped in frontal view, weakly lobulated; reaching to level of posterior margin of cirrus sac; ovarian isthmus in posterior fifth of ovary; Mehlis' gland posterior to ovarian isthmus. Vitellarium follicular, consisting of two lateral bands; each band consisting of two columns of large follicles, extending from anterior margin of proglottid to near posterior margin of ovary, interrupted by vagina and cirrus sac, not interrupted by ovary. Vitelline follicles irregular, 14-41 $(29 \pm 7 ; 13 ; 18)$ long by $15-40$ $(24 \pm 6 ; 13 ; 28)$ wide. Uterus median, thin-walled, sacciform, extending from near anterior part of proglottid to near ootype. Eggs not seen. Excretory ducts lateral.

Type host: Rhynchobatus cf. djiddensis 1 (Forsskål) (Rajiformes: Rhynchobatidae).

Type 1 ocality: Gulf of Oman $\left(25^{\circ} 11^{\prime} \mathrm{N} ; 60^{\circ} 33^{\prime} \mathrm{E}-25^{\circ} 25^{\prime} \mathrm{N}\right.$; $\left.57^{\circ} 43^{\prime} \mathrm{E}\right)$, Iran.

Additional localities: None.

Site of infection: Spiral intestine.

Prevalence of infection: One of six hosts infected (prevalence $=17 \%$ ).

Intensity: 16 specimens.

Type material: Holotype (ZUTC Platy.1311), 5 paratypes (ZUTC Platy. 1312-1316), 5 paratypes (ZMB E.7566), 2 SEM vouchers (ZUTC Platy. 1317, 1318).

E ty m o logy: The species is named in honour of Janine Caira, University of Connecticut, for her outstanding contribution to the study of tapeworm systematics and taxonomy.

Remarks. Acanthobothrium janineae sp. n. is a category 1 species according to the categories for Acanthobothrium species by Ghoshroy and Caira (2001) $(\leq 15 \mathrm{~mm}$ in total length, $\leq 50$ proglottids, $\leq 80$ testes, with symmetrical ovary). Based on the information taken from the original descriptions, 44 category 1 species have been described. Acanthobothrium janineae sp. n. differs from all congeners belonging to category 1 exept $A$. hypermekkolpos by its long vagina, extending along the midline of the proglottid to the anterior margin of the cirrus sac to extend well into the coils of the vas deferens. However, it differs from A. hypermekkolpos by having a shorter scolex proper (201-285 $\mu \mathrm{m}$ vs 313-418 $\mu \mathrm{m}$ ) and shorter total hook length $(97-115 \mu \mathrm{m} v s$ 116-127 $\mu \mathrm{m})$.

Other characters that are different than those of previously described species within category 1 refer to the total size and the number of proglottids. Acanthobothrium janineae is larger $(2.5-3.8 \mathrm{~mm})$ than $A$. gnomus Reyda et Caira, 2006 (0.8-1.4 mm), A. minusculus Marques, Brooks et Barriga, 1997 (1-2 mm) and A. asnihae Fyler et Caira, 2006 (1.0-2.1 mm), and shorter than A. paulum Linton, 1890 (4-19 mm), A. southwelli Subhapradha, 1955 (5 mm) and A. cartagenensis Brooks et Mayes, 1980 (25 mm).

The new species has fewer proglottids (7-10) than A. himanturi Brooks, 1977 (17-26), A. marplatensis Ivanov et Campbell, 1998 (18-30), A. royi Caira et Burge, 2001 (19-26), A. urolophi Schmidt, 1973 (22-28), A. laurenbrownae Campbell et Beveridge, 2002 (23-37), A. monksi Marques, Brooks et Barriga, 1997 (24-48), A. dollyae Caira et Burge, 2001 (33-48) and A. peruviense Reyda, 2008 (34-57), and more proglottids than $A$. jeanneae (4-5). It is an euapolytic worm unlike $A$. jalalii Maleki, Malek et Palm, 2013 and A. nanogravidum Zschoche, Caira et Fyler, 2011, both of which are apolytic.

There are other category 1 species that differ from the new species as follow: the scolex of $A$. janineae differs from that of $A$. lepidum Reyda et Caira, 2006 in that the scolex of the latter species has a conspicuously narrow posterior loculus relative to the anterior and middle loculi. The hook length is shorter in A. janineae (97-115 $\mu \mathrm{m})$ than in A. oceanharvestae Fyler, Caira et Jensen, 2009 (124-136 $\mu \mathrm{m})$ and $A$. atahualpai Marques, Brooks et Barriga, 1997 (193-195 $\mu \mathrm{m})$; the axial and abaxial prong lengths are longer in $A$. lineatum Campbell, 1969 (88-168 $\mu \mathrm{m}, 92-186 \mu \mathrm{m}$ vs 61-82 $\mu \mathrm{m}$, 46-65 $\mu \mathrm{m}$, respectively), and the new species differs from A. bartonae Campbell et Beveridge, 2002 in the lack of lateral spurs on the abaxial prong of hooks and the position of the tubercle in the mid-length of the axial prong (on the proximal surface of the axial prong $v s$ on the mid-length of the axial prong in A. bartonae). Acanthobothrium janineae has a longer cephalic peduncle (198-392 $\mu \mathrm{m})$ than $A$. ulmeri Vardo-Zalik et Campbell, $2011(48-176 \mu \mathrm{m})$ and $A$. $z a-$ inali Fyler et Caira, $2006(91-111 \mu \mathrm{m})$, and differs from A. odonoghuei Campbell et Beveridge, 2002 in the lack of small gladiate spinitriches on the cephalic peduncle.

Acanthobothrium janineae sp. n. possesses fewer testes (22-29) than A. guptai Shinde et Bhagwan, 2002 (44-45), A. clarkeae Campbell et Beveridge, 2002 (45-52) and A. pearsoni Williams, 1962 (56-60), and more testes than A. martini Campbell et Beveridge, 2002 (8-11). Acanthobothrium janineae differs from the following five category 1 species in the lack of postovarian testes: $A$. foulki Reyda et Caira, 2006, A. larsoni Reyda et Caira, 2006, A. marymichaelorum Towhig, Caira et Fyler, 2008, A. saliki Fyler et Caira, 2006 and A. zimmeri Fyler, Caira et Jensen, 2009. 
Other characters of the terminal genitalia, the position of the genital pores from the posterior end of the proglottid (63-79\%), distinguishes the new species from $A$. romanowi Fyler, Caira et Jensen, 2009 (34-45\%), A. schalli Vardo-Zalik et Campbell, 2011 (34-51\%) and A. westi Vardo-Zalik et Campbell, 2011 (45-56\%). The genital pores in the posterior fifth of the proglottid in A. fogeli Goldstein, 1964 distinguishes it from the new species. Unlike mathiasi Euzet, 1959, A. nicoyaense Brooks et McCoquodale, 1995 and $A$. rohdei Campbell et Beveridge, 2002, $A$. janineae lacks a vaginal sphincter. The ovarian lobes in $A$. janineae extend to the level of the cirrus sac in contrast to those of $A$. lentiginosum Vardo-Zalik et Campbell, 2011 and A. lintoni Goldstein, Henson et Schlicht, 1969.

Acanthobothrium fylerae sp. n.

Figs. 6-10, 17-22

ZooBank number for species:

urn:1sid:zoobank.org:act:4234313D-67C3-4A5B-A62D-5B3AA436900D

Description (based on whole mounts of 8 mature worms, 1 scolex examined with SEM and the whole mount of its voucher). Worms $1.8-3.3 \mathrm{~mm}(2.5 \pm 0.5 \mathrm{~mm} ; 8 ; 7)$ long; greatest width at level of scolex; $6-11(8 \pm 2 ; 8 ; 8)$ proglottids per worm; euapolytic. Scolex consisting of scolex proper and stout cephalic peduncle. Scolex proper with four bothridia, 200-274 $(228 \pm 22 ; 8 ; 8)$ long. Bothridia free posteriorly, 282-336 (310 $\pm 14 ; 8 ; 10)$ long by $109-140(119 \pm 9 ; 8 ; 11)$ wide; each with three loculi separated by two transverse septa, and a specialised anterior region in form of a muscular pad; muscular pad 65-89 (79 $\pm 9 ; 8 ; 10)$ long by 96-113 $(104 \pm 6 ; 8 ; 11)$ wide, bearing apical sucker and one pair of hooks at posterior margin; apical sucker $23-44(35 \pm 6 ; 8 ; 9)$ long by 40-57 (49 \pm 5 ; 8 ; 9) wide; anterior loculus $123-155$ (136 $\pm 11 ; 8 ; 10)$ long; middle loculus 41-72 (55 $\pm 8 ; 8 ; 11)$ long; posterior loculus 39-62 (51 \pm 7 ; 8; 11) long; ratio of locular length (anterior : middle : posterior) $1: 0.50-0.60: 0.39-0.59$ ( 1 : $0.42 \pm 0.42: 0.06 \pm 0.06 ; 8 ; 11)$; maximum width of scolex, 215-247 (230 $\pm 13 ; 8)$, at level of middle loculus. Velum present between medial margins of adjacent bothridia at level of posterior loculus.

Hooks bipronged, hollow, with tubercle on proximal surface of axial prongs; internal channels of axial and abaxial prongs continuous; lateral and medial hooks approximately equal in size; axial prongs slightly longer than abaxial prongs; axial prong of medial hook slightly longer than axial prong of lateral hook. Lateral hook measurements: A 42-51 (47 $\pm 3 ; 8 ; 12)$, B $62-73(70 \pm 4 ; 8 ; 12), \mathrm{C}$ 58-75 (64 $\pm 5 ; 8 ; 12)$, D 99-115 (109 $\pm 5 ; 8 ; 12)$, E 95-119 $(109 \pm 6 ; 8 ; 12)$, W 45-54 $(50 \pm 3 ; 8 ; 12)$. Medial hook measurements: A' 37-52 (44 $\pm 5 ; 8 ; 12)$, B $^{\prime} 70-89$ (79 \pm 5 ; 8; 12), C' 53-63 (57 $\pm 4 ; 8 ; 12)$, D' 107-136 (115 \pm 8 ; $8 ; 12)$, E' 92-116 (100 $\pm 6 ; 8 ; 12)$, W' 32-57 (45 $\pm 9 ; 8$; 12). Base of lateral and medial hooks approximately equal in length, embedded in muscular pad. Cephalic peduncle 144-281 (212 $\pm 42 ; 8)$ long by 88-136 (116 $\pm 16 ; 8)$ wide at mid-level.
Apical pad surface (Fig. 19) and distal bothridial surfaces (Fig. 21) covered with papilliform filitriches. Proximal bothridial surfaces (Fig. 20) covered with gladiate spinitriches interspersed with capilliform filitriches. Cephalic peduncle (Fig. 22) covered with densely arranged small gladiate spinitriches.

Proglottids acraspedote, protandrous. Immature proglottids $3-8(5.1 \pm 1.4 ; 8 ; 8)$ in number; mature proglottids $2-4(2.8 \pm 0.8 ; 8 ; 8)$ in number. Terminal mature proglottid 727-1303 (954 $\pm 174 ; 9 ; 8)$ long by 160-229 (194 \pm 20 ; 9; 8) wide; length : width ratio 4.2-6.7 : 1 (5.3 $\pm 0.9 ; 9 ; 9)$. Gravid proglottids not observed. Genital pores lateral, alternating irregularly, $57-72 \%(64 \pm 6 \% ; 9 ; 7)$ of proglottid length from posterior end. Testes irregularly oval in frontal view, 13-39 (21 $\pm 6 ; 9 ; 16)$ long by $23-54(37 \pm 9 ; 9 ; 16)$ wide, arranged in two regular columns anterior to ovarian isthmus, $21-31(26 \pm 3 ; 9 ; 10)$ in total number, 6-8 (6 \pm 1 ; $9 ; 16)$ in postporal field, no testes posterior to ovarian isthmus, atrophied in mature proglottids. Cirrus sac J-shaped, 88-192 (124 $\pm 27 ; 11 ; 11)$ long by $72-163(104 \pm 30 ; 11$; 11) wide, containing long coiled cirrus; cirrus expanded at base; entire cirrus covered with spinitriches. Massive vas deferens in anterior part of terminal mature proglottid.

Vagina thick-walled, sinuous, extending from ootype along midline of proglottid to anterior margin of cirrus sac, extending well into coils of vas deferens, then bent posteriorly to anterior margin of cirrus sac to common genital atrium; vaginal sphincter absent; seminal receptacle not seen. Ovary occupying posterior half of proglottid, symmetrical, 344-700 (504 $\pm 104 ; 9 ; 8)$ long, maximum width 86-121 $(102 \pm 14 ; 9 ; 8)$, H-shaped in frontal view, lobulated; reaching to level of posterior margin of cirrus sac; ovarian isthmus near posterior end of ovary; Mehlis' gland posterior to ovarian isthmus. Vitellarium follicular, consisting of two lateral bands; each band consisting of two columns of large follicles extending from anterior margin of proglottid to near posterior margin of ovary, interrupted by vagina and cirrus sac, not interrupted by ovary. Vitelline follicles irregular, 12-34 (21 \pm 6 ; 9; 16) long by 10-29 (21 \pm 5 ; 9; 16) wide. Uterus median, thin-walled, sacciform, extending from near anterior margin of proglottid to near ootype. Eggs not seen. Excretory ducts lateral.

Type host: Rhynchobatus cf. djiddensis 1 (Forsskål) (Rajiformes: Rhynchobatidae).

Type 1 ocality: Gulf of Oman $\left(25^{\circ} 11^{\prime} \mathrm{N} ; 60^{\circ} 33^{\prime} \mathrm{E}-25^{\circ} 25^{\prime} \mathrm{N}\right.$; $\left.57^{\circ} 43^{\prime} \mathrm{E}\right)$, Iran.

Additional localities: None.

Site of infection: Spiral intestine.

Prevalence of infection: One of six hosts sampled (prevalence $=17 \%)$.

Intensity: 10 specimens.

Type materia 1: Holotype (ZUTC Platy. 1319), 4 paratypes (ZUTC Platy. 1320-1323), 3 paratypes (ZMB E.7568), 1 SEM voucher (ZUTC Platy.1324).

Etymology: The species is named after Caroline Fyler, for her contributions to the study of systematics and taxonomy of the Acanthobothrium. 

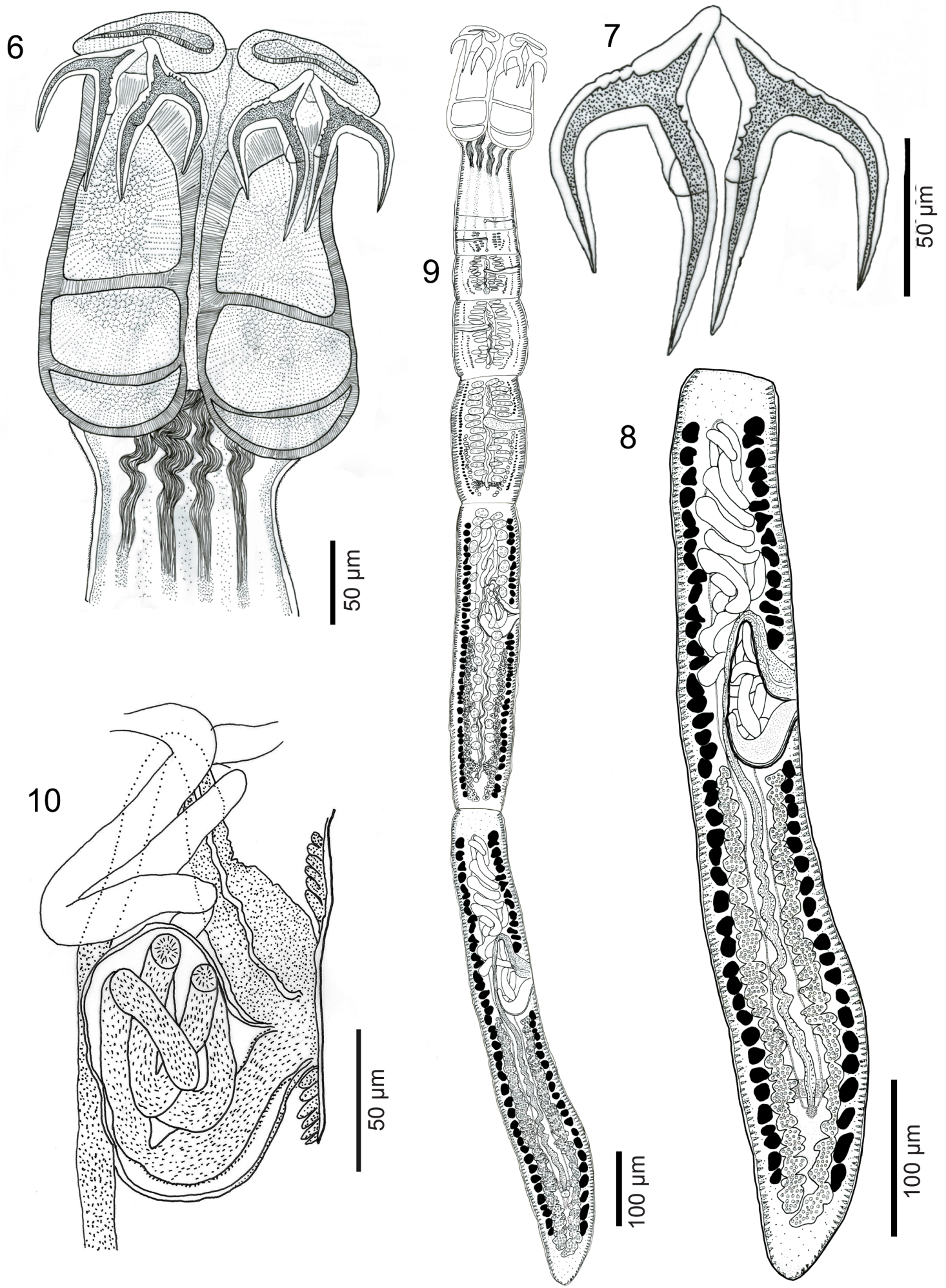

Figs. 6-10. Acanthobothrium fyleri sp. n. from Rhynchobatus cf. djiddensis 1. Fig. 6. Scolex. Fig. 7. Hooks. Fig. 8. Terminal mature proglottid. Fig. 9. Whole worm. Fig. 10. Terminal genitalia.

Remarks. Acanthobothrium fylerae sp. n. is a category 1 species according to the categories of Acanthobothrium species by Ghoshroy et Caira (2001) $(\leq 15 \mathrm{~mm}$ in total length, $\leq 50$ proglottids, $\leq 80$ testes, with symmetrical ovary). Currently, 45 category 1 species have been described. Acanthobothrium fylerae differs from all category 1 species in having a long vagina that ex- tends sinuously into the region of the vas deferens except $A$. hypermekkolpos and the new species $A$. janineae. Acanthobothrium fylerae is overall a much more robust worm than A. hypermekkolpos and possesses a flattened (vs dome-like) muscular pad and a shorter abaxial prong (62-73 $\mu \mathrm{m} v s$ 75-88 $\mu \mathrm{m})$. The total hook length is longer in the new species than in $A$. west $i$ and $A$. jeanneae 

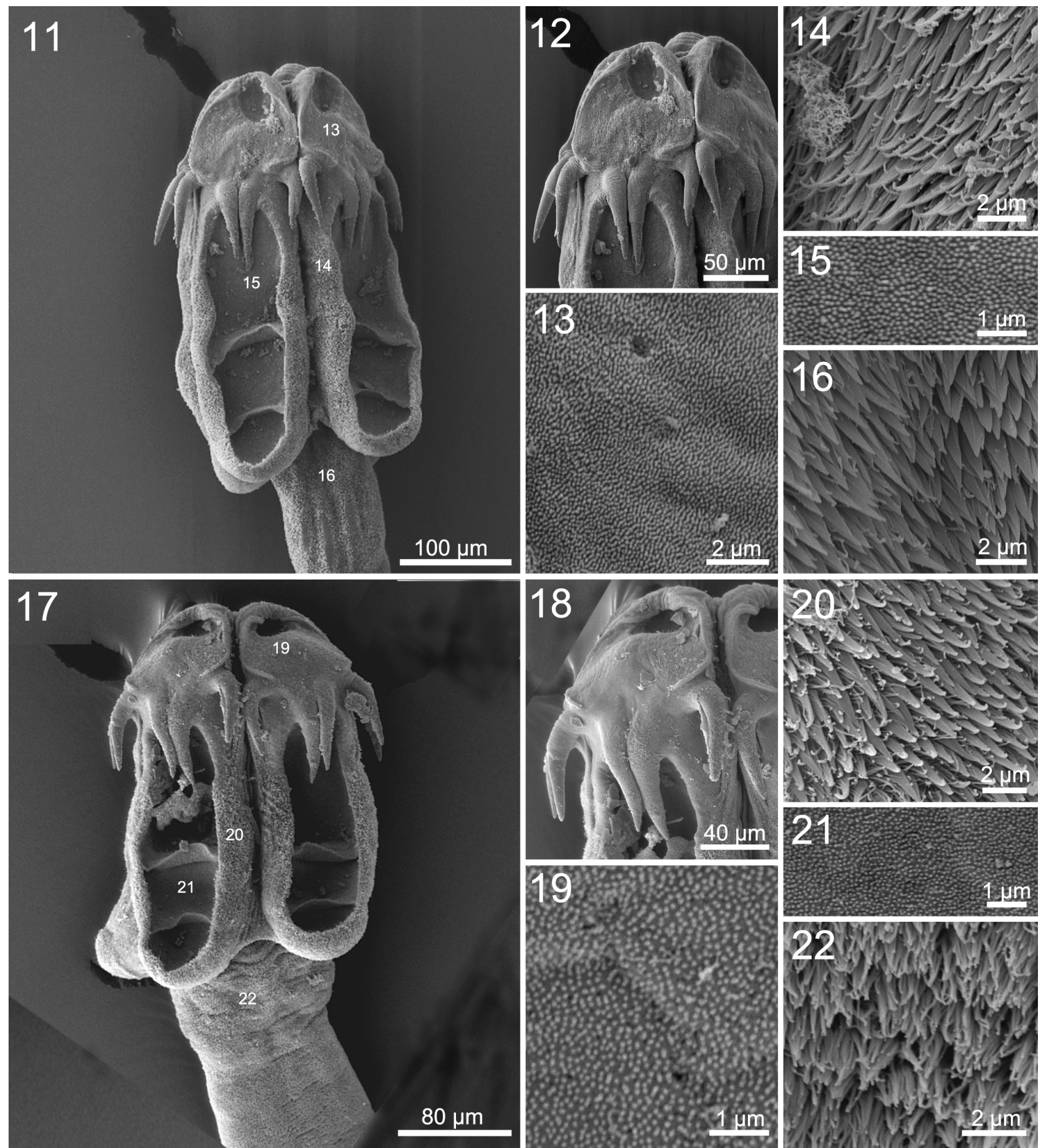

Figs. 11-16. Scanning electron micrographs of Acanthobothrium janineae sp. n. from Rhynchobatus cf. djiddensis 1. Fig. 11. Scolex. Note: small numbers on scolex correspond to the figures showing higher magnification images of these surfaces. Fig. 12. Apical pad and hooks. Fig. 13. Surface of apical pad. Fig. 14. Proximal bothridial surface. Fig. 15. Distal bothridial surface. Fig. 16. Cephalic peduncle surface. Figs. 17-22. Scanning electron micrographs of Acanthobothrium fylerae sp. n. from Rhynchobatus cf. djiddensis 1. Fig. 17. Scolex. Fig. 18. Apical pad and hooks. Fig. 19. Surface of apical pad. Fig. 20. Proximal bothridial surface. Fig. 21. Distal bothridial surface. Fig. 22. Cephalic peduncle surface.

(99-115 $\mu \mathrm{m} v s$ 63-72 $\mu \mathrm{m}$ and 79-95 $\mu \mathrm{m}$, respectively). Acanthobothrium fylerae differs from $A$. janineae in having wider bothridia (109-140 $\mu \mathrm{m}$ vs $87-105 \mu \mathrm{m})$, a wider scolex (215-247 $\mu \mathrm{m}$ vs 175-208 $\mu \mathrm{m})$, and a cephalic peduncle with gladiate spinitriches that are smaller than those in $A$. janineae In addition, the muscular pad is tri- angular in $A$. fylerae, instead of relatively globular, as in A. janineae.

Acanthobothrium fylerae is smaller than A. paulum, A. southwelli and A. cartagenensis (1.8-3.3 $\mathrm{mm}$ vs 4-19 mm, $5 \mathrm{~mm}$ and $25 \mathrm{~mm}$, respectively). It has fewer proglottids (6-11) than A. himanturi (17-26), A. marplat- 
ensis (18-30), A. royi (19-26), A. urolophi (22-28), A. laurenbrownae (23-37), A. monski (24-48), A. dollyae (33-48) and $A$. peruviense (34-57). The new species is euapolytic compared with the apolytic $A$. jalalii and $A$. nanogravidum. The new species differs from $A$. lepidum in lacking a conspicuously narrow posterior loculus relative to the anterior and middle loculi. The new species has a smaller posterior loculus than $A$. oceanharvestae (39-62 $\mu \mathrm{m} v s$ 75-110 $\mu \mathrm{m})$.

Acanthobothrium fylerae possesses a shorter hook length (99-119 $\mu \mathrm{m})$ than $A$. atahualpai (193-195 $\mu \mathrm{m})$ and a shorter axial prong length than $A$. lineatum $(62-73 \mu \mathrm{m}$ vs $88-168 \mu \mathrm{m})$. The new species differs from $A$. bartonae in the lack of lateral spurs on the abaxial prong of hooks and the position of the tubercle on the axial prong (proximal surface of the axial prong in the new species $v s$ midlength of the axial prong in A. bartonae). Acanthobothrium fylerae has a wider cephalic peduncle $(88-136 \mu \mathrm{m})$ than A. ulmeri (48-64), A. asnihae (50-71 $\mu \mathrm{m})$, A. gnomus $(50-95 \mu \mathrm{m})$ and $A$. zainali $(91-111 \mu \mathrm{m})$, and differs from $A$. odonoghuei in the lack of small gladiate spinitriches on the cephalic peduncle.

Acanthobothrium fylerae possesses fewer testes (21-31) than A. guptai (44-45), A. clarkeae (45-52) and A. pearsoni (56-60), and more testes than $A$. minusculus (6-10) and $A$. martini (8-11). The new species differs from the following five category 1 species in the lack of postovarian testes: A. foulki, A. larsoni, A. marymichaelorum, A. saliki and $A$. zimmeri. The position of the genital pores from the posterior end of the proglottid $(57-72 \%)$ can distinguish $A$. fylerae from $A$. romanowi (34-45\%), A. schalli (34-51\%) and from $A$. fogeli (in the posterior fifth of the proglottid). The new species can be differentiated from A. mathiasi, A. nicoyaense and A. rohdei in the lack of a vaginal sphincter. The ovarian lobes in $A$. fylerae extend to the level of the cirrus sac, but they do not reach the cirrus sac in A. lentiginosum and A. lintoni.

\section{Acanthobothrium asrinae sp. n. $\quad$ Figs. 23-27, 32-37}

ZooBank number for species:

urn:Isid:zoobank.org:act:48BDB3DF-FE27-432E-B966-181311E27548

Description (based on whole mounts of 3 mature worms, 1 scolex examined with SEM and the whole mount of its voucher). Worms $2.1-2.8 \mathrm{~mm}(2.3 \pm 0.3 \mathrm{~mm} ; 3 ; 3)$ long; greatest width at level of terminal proglottid, 11-15 $(13 \pm 2 ; 3 ; 3)$ proglottids per worm; euapolytic. Scolex consisting of scolex proper and conspicuous cephalic peduncle. Scolex proper with four bothridia, 125-188 (155 \pm 32 ; 3 ; 3) long. Bothridia free posteriorly, 227-318 (260 \pm 50 ; $3 ; 3)$ long by $99-117(105 \pm 8 ; 3 ; 3)$ wide; each with three loculi separated by two wide transverse septa, and a specialised anterior region in form of a muscular pad; muscular pad 80-98 (89 $\pm 8 ; 3 ; 5)$ long by $69-90(81 \pm 9 ; 3$; $5)$ wide, trapezoidal in shape, bearing apical sucker and one pair of hooks at posterior margin; apical sucker 26-29 (26 $\pm 1 ; 3 ; 5)$ long by $31-37(33 \pm 2 ; 3 ; 5)$ wide; anterior loculus $81-110(96 \pm 11.6 ; 3 ; 6)$ long; middle loculus 29-60 (38 $\pm 12 ; 3 ; 6)$ long; posterior loculus 24-37 (27 \pm 5 ;
3 ; 6) long; ratio of locular length (anterior : middle : posterior) $1: 0.3-0.58: 0.22-0.34(1: 0.39 \pm 0.06: 0.28 \pm 0.06$; 6); maximum width of scolex, 210-241 (217 \pm 21$)$, at level of middle loculus. Velum present between medial margins of adjacent bothridia at level of posterior loculus.

Hooks bipronged, hollow, with tubercle approximately on mid-length of axial prongs; internal channels of axial and abaxial prongs continuous; axial prongs longer than abaxial prongs; axial prong of medial hook longer than axial prong of lateral hook. Lateral hook measurements: A 40-54 (45 $\pm 6 ; 3 ; 7)$, B 60-66 (62 $\pm 2 ; 3 ; 7)$, C 47-52 (49 $\pm 7 ; 3 ; 7)$, D 95-113 (101 $\pm 7 ; 3 ; 7)$, E 88-105 $(94 \pm 7 ; 3 ; 7)$, W 34-43 $(37 \pm 3 ; 3 ; 7)$. Medial hook measurements: A' $31-44(37 \pm 5 ; 3 ; 7)$, B' 71-80 (75 $\pm 4 ; 3$; 7), C' 49-55 (51 $\pm 3 ; 3 ; 7)$, D' 102-121 (110 $\pm 8 ; 3 ; 7)$, E' 83-99 (89 $\pm 6 ; 3 ; 7)$, W' 28-44 (36 $\pm 6 ; 3 ; 7)$. Base of lateral hook overlapping medial hook, base of lateral hook slightly longer than medial hook base, embedded in muscular pad. Cephalic peduncle 216-350 $(280 \pm 67$; 3) long by $105-131(121 \pm 14 ; 3)$ wide at mid-level.

Apical pad surface (Fig. 34) and distal bothridial surfaces (Fig. 36) covered with papilliform filitriches. Proximal bothridial surfaces (Fig. 35) covered with gladiate spinitriches interspersed with capilliform filitriches. Cephalic peduncle (Fig. 37) covered with densely arranged gladiate spinitriches.

Proglottids acraspedote, protandrous. Immature proglottids $10-11(10.0 \pm 0.5 ; 3)$ in number; mature proglottids $1-4(2.3 \pm 1.5 ; 3)$ in number. Terminal mature proglottids $533-708(626 \pm 92 ; 4 ; 4)$ long by $148-234(188 \pm 35 ; 4 ; 4)$ wide; length : width ratio $2.8-4.7: 1$ (3.6 $\pm 0.8 ; 4 ; 4)$. Gravid proglottids not observed. Genital pores lateral, alternating irregularly, $55-58 \%(56 \pm 2 \% ; 3 ; 3)$ of proglottid length from posterior end. Testes irregularly oval in frontal view, $22-32(27 \pm 3 ; 4 ; 8)$ long by $32-49(39 \pm 7 ; 4 ; 8)$ wide, arranged in two regular columns anterior to ovarian isthmus, $25-29(27 \pm 2 ; 4 ; 4)$ in total number; $4-5(4.5 \pm 0.5 ; 4 ; 4)$ in postporal field; no testes posterior to ovarian isthmus. Cirrus sac ovoid, straight, $62-117(81 \pm 31$; 4; 3) long by 54-124 (91 $\pm 35 ; 4 ; 3)$ wide, containing short coiled cirrus; cirrus expanded at base; entire cirrus covered with spinitriches. Vas deferens extremely coiled anterior to cirrus sac.

Vagina thick-walled, sinuous, extending from ootype along midline of proglottid to anterior margin of cirrus sac, then following anterior margin of cirrus sac to common genital atrium; vaginal sphincter absent; seminal receptacle not seen. Ovary occupying posterior half of proglottid, symmetrical, 227-308 $(267 \pm 57 ; 4$; 2) long, maximum width 96-126 (114 $\pm 16 ; 4 ; 2)$, H-shaped in frontal view, lobulated, reaching to level of posterior margin of cirrus sac; Mehlis' gland posterior to ovarian isthmus. Vitellarium follicular, consisting of two lateral bands; each band consisting of two columns of large follicles, extending from anterior margin of proglottid to near posterior margin of ovary, interrupted by vagina and cirrus sac, not interrupted by ovary; vitelline follicles irregularly oval, 9-18 $(13 \pm 3 ; 4 ; 8)$ long by $12-20(16 \pm 3 ; 4 ; 8)$ wide. Uterus median, thin-walled, sacciform, extending from near an- 

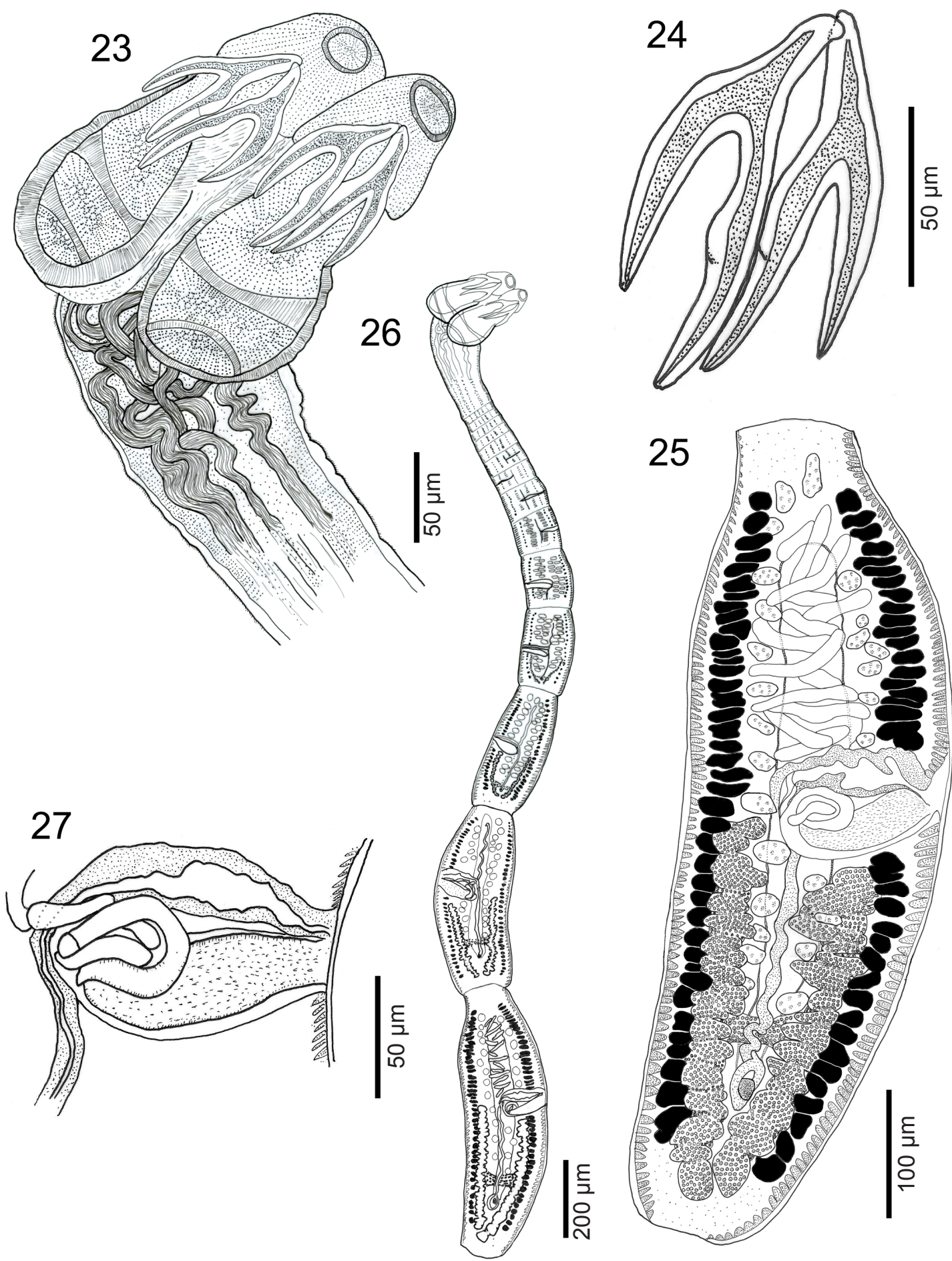

Figs. 23-27. Acanthobothrium asrinae sp. n. from Rhynchobatus cf. djiddensis 2. Fig. 23. Scolex. Fig. 24. Hooks. Fig. 25. Terminal mature proglottid. Fig. 26. Whole worm. Fig. 27. Terminal genitalia.

terior margin of proglottid to near ootype. Eggs not seen. Excretory ducts lateral.

Type host: Rhynchobatus cf. djiddensis 2 (Forsskål) (Rajiformes: Rhynchobatidae).

Type locality: Persian Gulf $\left(26^{\circ} 15^{\prime} \mathrm{N} ; 53^{\circ} 02^{\prime} \mathrm{E}-27^{\circ} 04^{\prime} \mathrm{N}\right.$; $\left.57^{\circ} 01^{\prime} \mathrm{E}\right)$, Iran.

Additional localities: None.

Site of infection: Spiral intestine.
Prevalence of infection: One of two hosts sampled (prevalence $=50 \%)$.

Intensity: 5 specimens.

Type material: Holotype (ZUTC Platy.1325), 1 paratype (ZUTC Platy.1326), 1 paratype (ZMB E.7569), 1 SEM voucher (ZUTC Platy.1327).

Etymology: This species is named after the senior author's wife, Asrin Hassani, for her interest in biology and her encouragement during this project. 
Remarks. Acanthobothrium asrinae sp. n. is a category 1 species, according to Ghoshroy and Caira (2001) ( $\leq 15 \mathrm{~mm}$ in total length, $\leq 50$ proglottids, $\leq 80$ testes, with symmetrical ovary). It can be easily distinguished from all 46 category 1 species except $A$. bartonae from Rhynchobatus djiddensis in the shape of the hooks. The new species can also be differentiated from $A$. bartonae in the lack of lateral spurs on the prongs and a shorter hook length (95-113 $\mu \mathrm{m} v s$ 125-134 $\mu \mathrm{m})$.

In addition to hook shape, $A$. asrinae differs from other category 1 species as follows: the new species is larger (2.1-2.8 $\mathrm{mm})$ than A. gnomus $(0.8-1.4 \mathrm{~mm})$, A. minusculus (1-2 mm), A. asnihae (1.0-2.1 mm), and shorter than A. paulum (4-19 mm), A. romanowi (4.0-7.1 mm), A. marplatensis (4.8-8.4 $\mathrm{mm}), A$. southwelli $(5 \mathrm{~mm})$ and $A$. cartagenensis $(25 \mathrm{~mm})$. It has fewer proglottids (11-15) than A. himanturi (17-26), A. royi (19-26), A. urolophi (22-28), A. laurenbrownae (23-37), A. monski (24-48), A. dollyae (33-48), A. peruviense (34-57), and more proglottids than $A$. jeanneae (4-5) and $A$. nanogravidum (4-6). The new species is euapolytic compared with the apolytic $A$. jalalii.

Acanthobothrium asrinae differs from A. lepidum in lacking a conspicuously reduced posterior loculus width relative to the anterior and middle loculi. The new species has a smaller hook length $(95-113 \mu \mathrm{m})$ than $A$. atahualpai $(193-195 \mu \mathrm{m})$ and the lateral axial prong is longer in A. lineatum $(88-168 \mu \mathrm{m} v s$ 60-66 $\mu \mathrm{m})$. The new species has a longer cephalic peduncle $(216-350 \mu \mathrm{m})$ than $A$. ulmeri $(48-176 \mu \mathrm{m})$ and $A$. zainali $(91-111 \mu \mathrm{m})$, and differs from $A$. odonoghuei in the lack of small gladiate spinitriches on the cephalic peduncle.

The terminal mature proglottid in the new species is shorter $(533-708 \mu \mathrm{m})$ than that in $A$. oceanharvestae (822-1237 $\mu \mathrm{m})$. Acanthobothrium asrinae possesses fewer testes (25-29) than A. guptai (44-45), A. clarkeae (45-52) and $A$. pearsoni (56-60), and more testes than A. martini (8-11) and A. asnihae (8-12). Acanthobothrium asrinae sp. $\mathrm{n}$. differs from the following 5 category 1 species in the lack of postovarian testes: $A$. foulki, A. larsoni, A. marymichaelorum, A. saliki and A. zimmeri. The position of the genital pores from the posterior end of the proglottid in $A$. asrinae (55-58\%) distinguishes it from A. schalli (34-51\%). The genital pores in the posterior fifth of the proglottid in $A$. fogeli can distinguish it from the new species, which also differs from A. mathiasi, $A$. nicoyaense and $A$. rohdei in the lack of a vaginal sphincter. Acanthobothrium hypermekkolpos has a long and sinuous vagina unlike $A$. asrinae with a short vagina. The ovarian lobes in $A$. asrinae extend to the level of the cirrus sac, not reaching the cirrus sac in $A$. lentiginosum, $A$. lintoni and $A$. westi. The new species can be distinguished from the two previously described species described here, in the more posterior position of the tubercle on the axial prongs and from $A$. fylerae in having shorter ovarian lobes (227-308 $\mu \mathrm{m} v s$ 472-799 $\mu \mathrm{m}$ and 344-700 $\mu \mathrm{m}$, respectively). It also differs from $A$. fylerae and $A$. janineae in a smaller posterior loculus (24-37 $\mu \mathrm{m}$ vs 39-62 $\mu \mathrm{m}$ and 46-74 $\mu \mathrm{m})$.
Acanthobothrium jamesi sp. n.

Figs. 28-31, 38-43

ZooBank number for species:

urn:1sid:zoobank.org:act:30AF3E36-01B5-4D00-A3B3-6A693F18E50D

Description (based on whole mounts of 2 mature worms, 1 scolex examined with SEM and the whole mount of its voucher). Worms $1.4-1.7 \mathrm{~mm}(1.5 \pm 0.2 ; 2)$ long; greatest width at level of scolex; $4-5(4.5 \pm 0.7 ; 2)$ proglottids per worm; euapolytic. Scolex consisting of scolex proper and conspicuous cephalic peduncle. Scolex proper with four bothridia, 172-216 (194 \pm 31 ; 2) long. Bothridia free posteriorly, 219-284 (251 $\pm 46 ; 2)$ long by $71-88(79 \pm 12 ; 2)$ wide; each with three loculi and specialised anterior region in form of muscular pad; muscular pad 39-55 $(46 \pm 8 ; 2 ; 3)$ long by $55-78(64 \pm 12 ; 2 ; 3)$ wide, trapezoidal in shape, bearing apical sucker and one pair of hooks at posterior margin; apical sucker $15-18(16 \pm 2 ; 2 ; 3)$ long by $21-28$ (23 $\pm 4 ; 2 ; 3)$ wide; anterior loculus $103-119$ (112 $\pm 8 ; 2$; 3) long; middle loculus $38-44(42 \pm 3 ; 2 ; 3)$ long; posterior loculus $35-41(38 \pm 3 ; 2 ; 3)$ long; ratio of locular length (anterior : middle : posterior) $1: 0.36-0.38: 0.30-0.39$ (1: $0.36 \pm 0.33: 0.01 \pm 0.04 ; 2 ; 3)$. Maximum width of scolex, 138-217 (177 $\pm 55 ; 2)$, at level of middle loculus. Velum absent.

Apical pad surface (Fig. 40) and distal bothridial surfaces (Fig. 42) covered with papilliform filitriches. Proximal bothridial surfaces (Fig. 41) covered with gladiate spinitriches interspersed with capilliform filitriches. Cephalic peduncle (Fig. 43) with densely arranged gladiate spinitriches.

Hooks bipronged, hollow, with tubercle on proximal surface of axial prong; internal channels of axial and abaxial prongs continuous, smooth; axial prongs approximately equal to abaxial prongs; lateral and medial hooks approximately equal in size. Lateral hook measurements: A 26-31 $(28 \pm 2 ; 2 ; 4)$, B 47-62 (53 $\pm 6 ; 2 ; 4)$, C 46-57 (51 \pm 5 ; $2 ; 4)$, D 69-86 (77 $\pm 7 ; 2 ; 4)$, E 72-87 (80 $\pm 7 ; 2 ; 4), \mathrm{W}$ $26-38(32 \pm 5 ; 2 ; 4)$. Medial hook measurements: A' 23-31 $(27 \pm 4 ; 2 ; 4)$, B' 53-62 (57 $\pm 4 ; 2 ; 4), C^{\prime} 47-57$ (50 \pm 5; $2 ; 4)$, D' 74-87 (81 $\pm 6 ; 2 ; 4)$, E' 70-89 (77 $\pm 8 ; 2 ; 4)$ W' $24-45(33 \pm 11 ; 2 ; 4)$. Bases of lateral and medial hooks approximately equal in length, embedded in muscular pad. Cephalic peduncle $435-547(491 \pm 79 ; 2)$ long by $51-58$ $(54 \pm 5 ; 2)$ wide at mid-level.

Proglottids acraspedote, protandrous. Immature proglottids 3-4 $(3.5 \pm 0.7 ; 2)$ in number; single mature proglottid, $386-414(396 \pm 15 ; 3)$ long by $147-159(153 \pm 6.1 ; 3)$ wide, length : width ratio $2.5-2.7: 1(2.5 \pm 0.1 ; 3)$. Gravid proglottids not observed. Genital pores lateral, alternating irregularly, $71-74 \%(72 \pm 2 \% ; 3 ; 3)$ of proglottid length from posterior end. Testes oval in frontal view, 17-25 $(20 \pm 3 ; 3 ; 6)$ long by $32-47(38 \pm 6 ; 3 ; 6)$ wide, arranged in two regular columns from anterior to posterior end of proglottid, $21-22(21 \pm 1 ; 3)$ in total number, $4-6(5 \pm 1 ; 3)$ in postporal field, $4-7(5 \pm 2 ; 3)$ in postovarian field. Cirrus sac oval shaped, straight, 27-32 $(29 \pm 3 ; 3)$ long by $79-100$ $(91 \pm 11 ; 3)$ wide, containing short coiled cirrus; base and most of cirrus covered with spinitriches. 

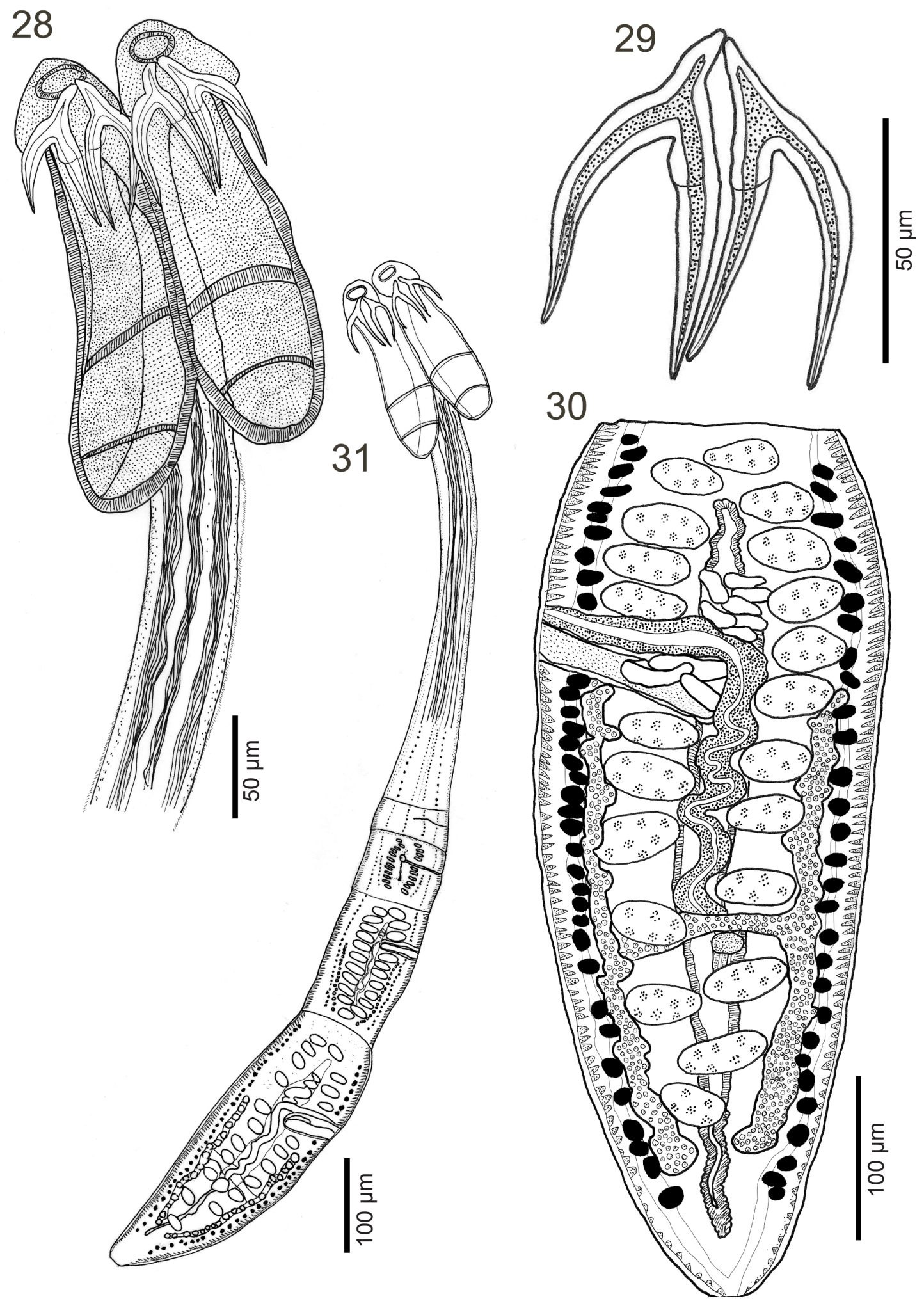

Figs. 28-31. Acanthobothrium jamesi sp. n. from Rhynchobatus cf. djiddensis 2. Fig. 28. Scolex. Fig. 29. Hooks. Fig. 30. Terminal mature proglottid. Fig. 31. Whole worm.

Vagina thick-walled, sinuous, extending from ootype along midline of proglottid to anterior margin of cirrus sac, then following anterior margin of cirrus sac to common genital atrium; vaginal sphincter absent; seminal receptacle not seen. Ovary occupying posterior half of proglottid, symmetrical, 192-214 (202 $\pm 11 ; 3)$ long, maximum width
95-110 $(105 \pm 9 ; 3)$, H-shaped in frontal view, weakly lobulated; extending to posterior margin of cirrus sac; Mehlis' gland posterior to ovarian isthmus.

Vitellarium follicular, consisting of two lateral bands; each band consisting of two columns of small follicles, extending from anterior margin of proglottid to near posterior 

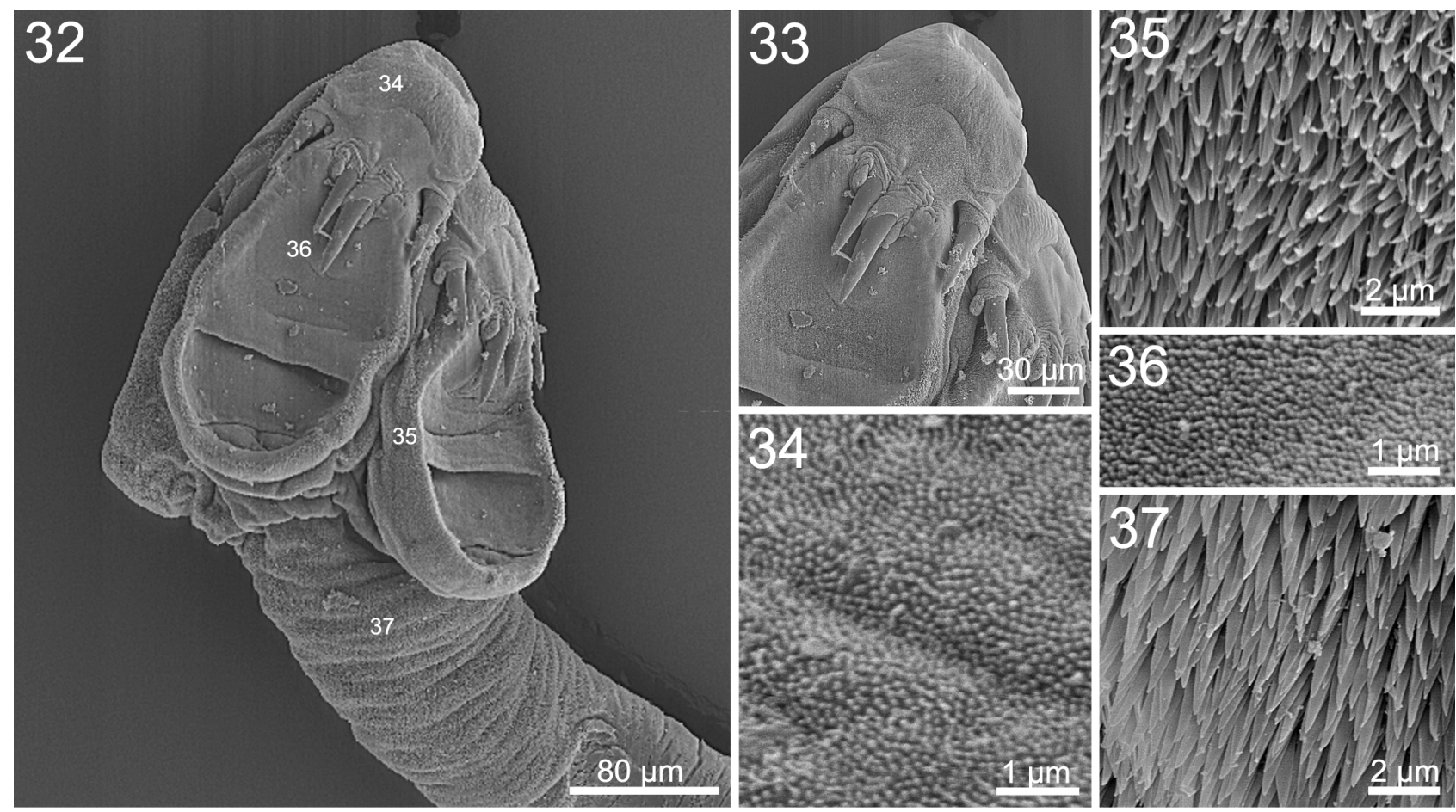

\section{8}
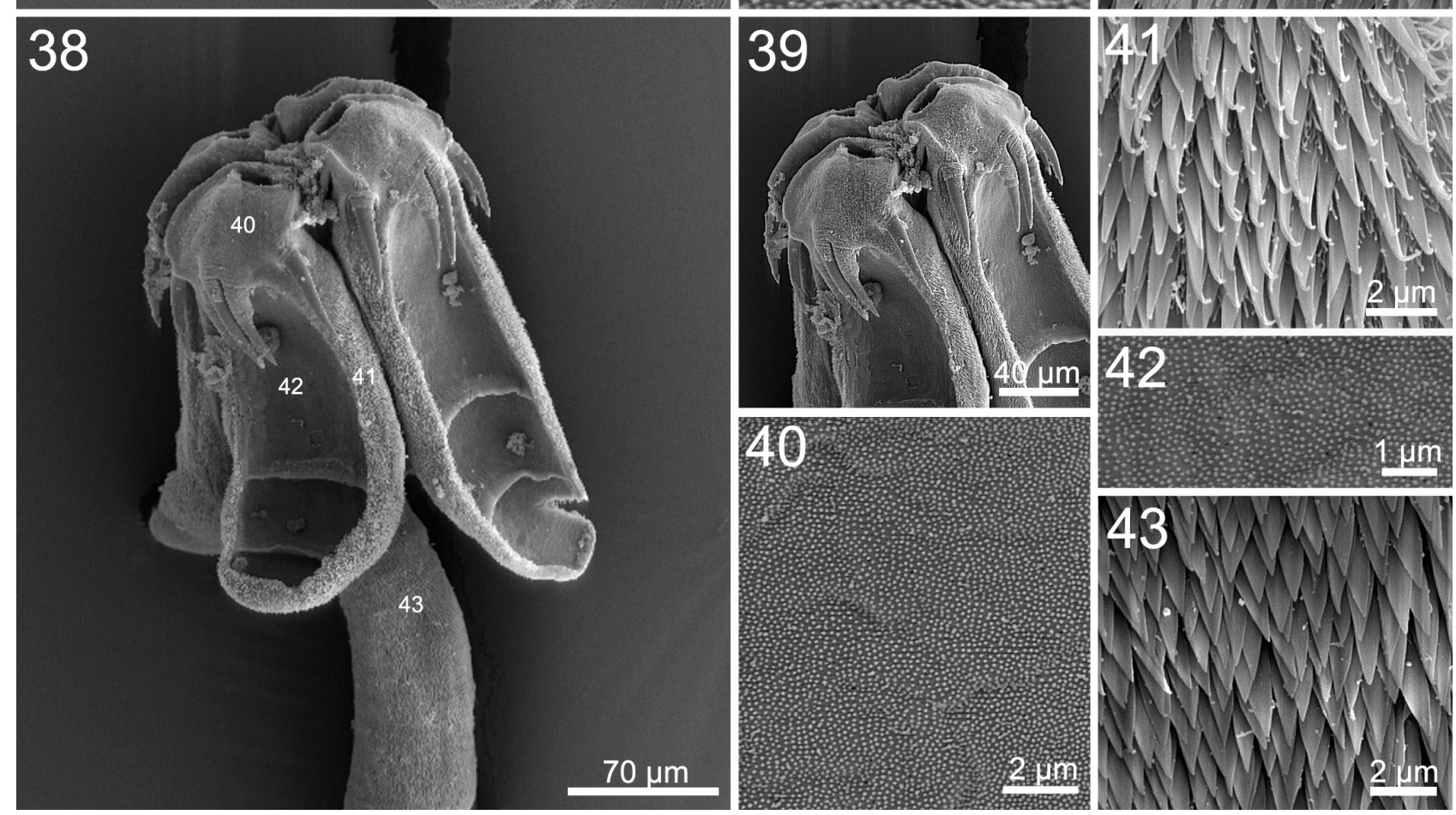

Figs. 32-37. Scanning electron micrographs of Acanthobothrium asrinae sp. n. from Rhynchobatus cf. djiddensis 2. Fig. 32. Scolex (small numbers on scolex correspond to the figures showing higher magnification images of these surfaces). Fig. 33. Apical pad and hooks. Fig. 34. Surface of apical pad. Fig. 35. Proximal bothridial surface. Fig. 36. Distal bothridial surface. Fig. 37. Cephalic peduncle surface. Figs. 38-43. Scanning electron micrographs of Acanthobothrium jamesi sp. n. from Rhynchobatus cf. djiddensis 2. Fig. 38. Scolex. Fig. 39. Apical pad and hooks. Fig. 40. Surface of apical pad. Fig. 41. Proximal bothridial surface. Fig. 42. Distal pothridial surface. Fig. 43. Cephalic peduncle surface.

margin of ovary, interrupted by vagina and cirrus sac, not interrupted by ovary; vitelline follicles $7-10(9 \pm 1 ; 3 ; 6)$ long by $10-16(13 \pm 2 ; 3 ; 6)$ wide. Uterus median, thickwalled, sacciform, extending from near anterior margin of proglottid to near posterior end. Eggs not seen. Excretory ducts lateral.
Type host: Rhynchobatus cf. djiddensis 2 (Rajiformes: Rhynchobatidae).

Type 1 ocality: Persian Gulf $\left(26^{\circ} 15^{\prime} \mathrm{N} ; 53^{\circ} 02^{\prime} \mathrm{E}-27^{\circ} 04^{\prime} \mathrm{N}\right.$; $\left.57^{\circ} 01^{\prime} \mathrm{E}\right)$, Iran.

Additional localities: None.

Site of infection: Spiral intestine.

Prevalence of infection: One of two hosts sampled 


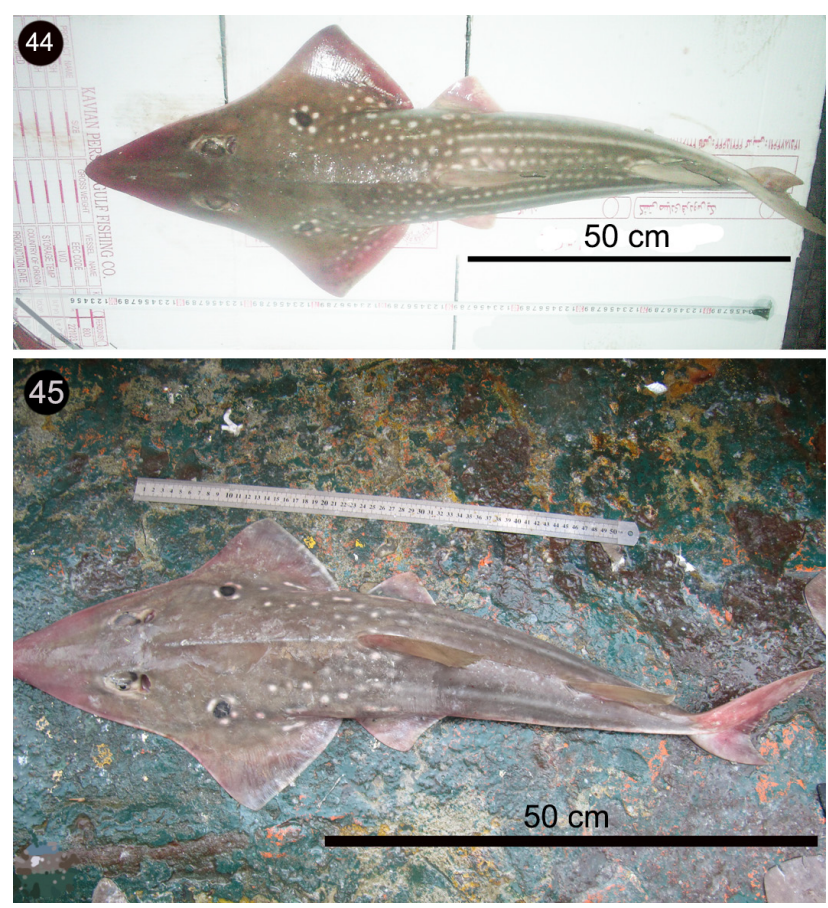

Fig 44. Dorsal view of adult male of Rhynchobatus cf. djiddensis 1 from the Gulf of Oman. Fig. 45. Dorsal view of adult male of Rhynchobatus cf. djiddensis 2 from the Persian Gulf.

(prevalence $=50 \%$ ).

Inten sity: 4 specimens.

Type material: Holotype (ZUTC Platy.1328), 1 paratype (ZMB E.7570), 1 SEM voucher (ZUTC Platy.1329).

Etymology: This species is named in the honor of Brian James, University of Wales, Swansea, for introducing the wonderful world of marine parasites to the second author (Masoumeh Malek) during her $\mathrm{PhD}$ project.

Remarks. Acanthobothrium jamesi sp. n. is a category 1 species according to the categorisation system by Ghoshroy and Caira (2001) $(\leq 15 \mathrm{~mm}$ in total length, $\leq 50$ proglottids, $\leq 80$ testes, with symmetrical ovary). It differs from all but ten of the 47 category 1 species in the possession of postovarian testes. Acanthobothrium jamesi differs from A. cannoni Campbell et Beveridge, 2002, A. wedli Robinson, 1959 and A. blairi Campbell et Beveridge, 2002 in its small size (1.4-1.7 mm vs 8.3-10.2 mm, 9.5-13.5 mm and 10.5-16.8 mm, respectively). The new species differs from A. zimmeri, A. saliki and A. popi Fyler, Caira et Jensen, 2009 in its possession of fewer proglottids (4-5 vs 10-19, 11-19 and 14-20, respectively). Acanthobothrium jamesi can be distinguished from $A$. southwelli with its smaller size (1.4-1.7 mm vs $5 \mathrm{~mm}$ ) and fewer testes (21-22 vs 34). The new species differs from $A$. foulki in the lack of a vaginal sphincter. Acanthobothrium jamesi is most similar to A. larsoni, but differs from this species and A. marymichaelorum in having shorter ovarian lobes (192-214 $\mu \mathrm{m}$ vs 252-500 $\mu \mathrm{m}$ and $240-456 \mu \mathrm{m}$, respectively).

\section{DISCUSSION}

The present study adds four new species of Acanthobothrium that have been described from Rhynchobatus cf. djiddensis 1 and $R$. cf. djiddensis 2, resulting in 14 species that are known from the genus Rhynchobatus. The new species described here, when added to the two known from Pastinachus cf. sephen (see Maleki et al. 2013), brings the total number of Acanthobothrium species in the Persian Gulf and Gulf of Oman to six.

Rhynchobatus djiddensis is the first species described within the genus Rhynchobatus. In the past, most of the so far recorded Rhynchobatus species have been synonymised with $R$. djiddensis (see Campagno and Last 2008). As a consequence, $R$. djiddensis has been the specific identity assigned to hosts of this genus in most instances in the past. Fyler and Caira (2010) addressed this problem and discussed the true identity of species of Rhynchobatus that host of Acanthobothrium. They questioned the host identifications of Campbell and Beveridge (2002) in Australia and Yang and Lin (1994) in China, based on observations of Last and Stevens (2009) who argued that $R$. djiddensis is restricted in distribution to the Western Indian Ocean. Rhynchobatus djiddensis is so far restricted to the Western Indian Ocean (Last and Stevens 2009) and occurs in Indian offshore waters (Raje et al. 2007). Therefore, according to Fyler and Caira (2010), it is most likely that R. djiddensis and $R$. laevis are candidate hosts of $A$. rhynchobatidis Subhapradha, 1955, originally described from Indian waters. Our host specimens do not entirely correspond to the original description of $R$. djiddensis, resulting in our tentative host identification as Rhynchobatus $\mathrm{cf}$. djiddensis 1 and $R$. cf. djiddensis 2 for the four new Acanthobothrium species recorded here. Further, none of the Acanthobothrium species encountered in this study remotely resembled A. rhynchobatidis. The exact type host identification will require further taxonomic sampling and evaluation of newly collected hosts using the morphological and molecular means.

Rhynchobatus djiddensis as originally described differs from the Persian Gulf and Gulf of Oman specimens. Rhynchobatus djiddensis has coloration with olive-green on dorsal side and two blackish pectoral spots edged with four white spots. The two different forms of Rhynchobatus seen in the Gulf of Oman (Fig. 44) and Persian Gulf (Fig. 45) differ in colouration pattern. The Gulf of Oman specimens have olive-green color on the dorsal side, two blackish pectoral spots edged with six white spots with white spots spreading at regular rows on the upper body; the Persian Gulf specimens have gray color on the dorsal side with white spots spreading irregularly only around the first dorsal fin (Fig. 45). Therefore, we are not confident about the true host identity. Numerous records of ' $R$. djiddensis' from the Indo-West Pacific cannot be confirmed because of adequate descriptions and illustrations; voucher specimens are also not available (Campagno and Last 2008). Our use of numerical designations for the two forms of Rhynchobatus seen here (i.e. $R$. cf. djiddensis 1 and $R$. cf. djiddensis 2) serves to ground the identity of the hosts of the new species of Acanthobothrium described here. These Rhynchobatus forms have two different Acanthobothrium species, respectively. Acanthobothrium janineae sp. n. and A. fylerae sp. n. occur in Rhynchobatus cf. djiddensis 1 from the Gulf of 
Oman, and $A$. asrinae sp. n. and $A$. jamesi sp. n. occur in Rhynchobatus cf. djiddensis 2 from the Persian Gulf. In the lack of robust taxonomic studies on the true host identity, we suggest that the different Acanthobothrium species indicate two different Rhynchobatus forms in the region. However, it must be kept in mind that different parasite species might be also related to possible zoogeographical variations of their hosts inside the Persian Gulf and the Gulf of Oman.

Earlier studies have grouped different Acanthobothrium species, based on morphological similarities, into different zoogeographical regions despite the lack of a phylogenetic hypothesis (Marques et al. 1995, 1997). Based on putative synapomorphies, these authors found similarities between the fauna of the Indian Ocean and the Western Pacific. Our new species A. janineae is morphologically most similar to A. hypermekkolpos from Australia in having a long vagina. Each of the two cestodes is from a different Rhynchobatus species. There also seems to be a relationship between $A$. asrinae sp. n. and $A$. bartonae from Australia based on their highly similar hook morphology. Both distinctive characters seem to be restricted to species of Acanthobothrium in the Indo-Pacific region. A. larsoni is by far the most similar morphologically to $A$. jamesi $\mathrm{sp}$. n., even though $A$. larsoni is from a different region and from a different host genus and species, supporting the notion by Marques et al. (1997) that Acanthobothrium might be a good model for host-parasite co-evolutionary studies.
The description of $A$. jamesi brings the total number of Acanthobothrium species with postovarian testes to 11 . Again, this feature is restricted to the Indo-Pacific region (Fyler and Caira 2006, Reyda and Caira 2006, Twohig et al. 2008, Fyler et al. 2009). Most of these species are recorded from dasyatid stingrays of the genus Himantura Muller et Henle, including A. cannoni, A. foulki, A. larsoni, A. marymichaelorum, $A$. saliki, $A$. popi and $A$. zimmeri (Campbell and Beveridge 2002, Fyler and Caira 2006, Reyda and Caira 2006, Twohig et al. 2008). Four species were found in the Rajiformes, including A. blairi from Raja whitleyi (Iredale), A. wedli from Raja nasuta (Muller et Henle), and $A$. southwelli and A. jamesi from R. djiddensis. Two species parasitise guitarfish, the Rhinobatidae and Rhynchobatidae from India and Iran, respectively. Further studies on guitarfish and dasytid rays from the Persian Gulf and Gulf of Oman most likely will lead to further findings of species of Acanthobothrium with postovarian testes.

Acknowledgements. We gratefully acknowledge the cooperation of Tooraj Valinasab from the Fisheries Research Organisation of Iran for supporting the host collection, the Iranian Ministry of Science, Research and Technology, the University of Tehran, Department of Environment of Iran, and the Electron Microscopic Centre at the University of Rostock, Germany. We also would like to thank Janine Caira for her assistance in comparison of the specimens with type material. This study was supported in part by the NSF Planetary Biodiversity Inventory Project awards (Award Nos. 0818696 and 0818823).

\section{REFERENCES}

Bonfil R., Abdallah M. 2004: Field Identification Guide to the Sharks and Rays of the Red Sea and Gulf of Aden. Food and Agriculture Organization of the United Nations, Rome, $71 \mathrm{pp}$.

Campagno L.J., Last P.R. 2008: A new species of wedgefish, Rhynchobatus palpebratus sp. nov. (Rhynchobatoidei: Rhynchobatidae), from the Indo-West Pacific. In: P.R. Last, W.T White and J.J. Pogonoski (Eds.), Descriptions of New Australian Chondrichthyans. CSIRO Marine and Atmospheric Research Paper 32: 227-240.

Campagno L.J., Last P.R. 2010: A new species of wedgefish, Rhynchobatus springeri (Rhynchobatoidei, Rhynchobatidae), from the Western Pasific. In: P.R. Last, W.T. White and J.J. Pogonoski (Eds.), Descriptions of New Sharks and Rays from Borneo. CSIRO Marine and Atmospheric Research Paper 32: 77-88.

Campbell R.A., Beveridge I. 2002: The genus Acanthobothrium (Cestoda: Tetraphyllidea: Onchobothriidae) parasitic in Australian elasmobranch fishes. Invertebr. Syst. 16: 237-344.

Carpenter K.E., Krupp F., Jones D.A., Zajonz U. 1997: FAO Species Identification Field Guide for Fishery Purposes. Living Marine Resources of Kuwait, Eastern Saudi Arabia, Bahrain, Qatar, and the United Arab Emirates. Food and Agriculture Organization of the United Nations, Rome, $293 \mathrm{pp}$.

Chervy L. 2009: Unified terminology for cestode microtriches: a proposal from the International Workshops on Cestode Systematics in 2002-2008. Folia Parasitol. 56: 199-230.

EuzET L. 1959: Recherches sur les cestodes tétraphyllides des Sélaciens des Côtes de France. PhD thesis, University of Montpellier, France, $263 \mathrm{pp}$.

Fyler C.A. 2011: An extremely hyperapolytic Acanthobothrium species (Cestoda: Tetraphyllidea) from the Japanese wobbegong, Orectolobus japonicus (Elasmobranchii: Orectolobiformes) in Taiwan. Comp. Parasitol. 78: 4-14.
Fyler C.A., Caira J.N. 2006: Five new species of Acanthobothrium (Cestoda: Tetraphyllidea) from the freshwater whipray (Himantura chaophraya). J. Parasitol. 92: 105-125.

Fyler C.A., Caira J.N. 2010: Phylogenetic status of four new species of Acanthobothrium (Cestoda: Tetraphyllidea) parasitic on the wedgefish Rhynchobatus laevis (Elasmobranchii: Rhynchobatidae): implications for interpreting host associations. Invertebr. Syst. 24: 419-433.

Fyler, C.A., CAira J.N., Jensen K. 2009: Five new species of Acanthobothrium (Cestoda: Tetraphyllidea) from an unusual species of Himantura (Rajiformes: Dasyatidae) from northern Australia. Folia Parasitol. 56: 107-128.

Ghoshroy S., Caira J.N. 2001: Four new species of Acanthobothrium (Cestoda: Tetraphyllidea) from the whiptail stingray Dasyatis brevis in the Gulf of California, Mexico. J. Parasitol. 87: 354-372.

Haseli M., Malek M., Palm H.W. 2010: Trypanorhynch cestodes of elasmobranchs from the Persian Gulf. Zootaxa. 2492: 28-48.

IvANoV V.A. 2005: A new species of Acanthobothrium (Cestoda: Tetraphyllidea: Onchobothriidae) from the ocellate river stingray, Potamotrygon motoro (Chondrichthyes: Potamotrygonidae), in Argentina. J. Parasitol. 91: 390-396.

Last P.R., Stevens J.D. 2009: Sharks and Rays of Australia. Second edn. CSIRO Publications, Tasmania, $644 \mathrm{pp}$.

Maleki L., MaleK M., Palm H.W. 2013: Two new species of Acanthobothrium (Tetraphyllidea: Onchobothriidae) from Pastinachus cf. sephen (Myliobatiformes: Dasyatidae) from the Persian Gulf and Gulf of Oman. Folia Parasitol. 60: 448-456.

Marques F., Brooks D.R., Barriga R. 1997: Six species of Acanthobothrium (Eucestoda: Tetraphyllidea) in stingrays (Chondrichthyes: Rajiformes: Myliobatoidei) from Ecuador. J. Parasitol. 83: 475-484. 
Marques F., Brooks D.R., Monks S. 1995: Five new species of Acanthobothrium van Beneden, 1849 (Eucestoda: Tetraphyllidea: Onchobothriidae) in stingrays from the Gulf of Nicoya, Costa Rica. J. Parasitol. 81: 942-951.

Raje S.G., Sivakami S., Mohanraj G., Kumar P.M., Raju A., Joshi K.K. 2007: An Atlas on the Elasmobranch Fishery Resources of India. CMFRI Special Publications No. 95, 253 pp.

RANDAlL J.E. 1995: Coastal Fishes of Oman. University of Hawaii Press, Honolulu, 439 pp.

Reyda F.B., Caira J.N. 2006: Five new species of Acanthobothrium (Cestoda: Tetraphyllidea) from Himantura uarnacoides
(Myliobatiformes: Dasyatidae) in Malaysian Borneo. Comp. Parasitol. 73: 49-71.

SubHapRadHa C.K. 1955: Cestode parasites of fishes of Madras Coast. Ind. J. Helminthol. 7: 41-132.

Twohig M.E., Caira J.N., Fyler C.A. 2008: Two new cestode species from the dwarf whipray, Himantura walga (Batoidea: Dasyatidae), from Borneo with comments on site and mode of attachment. J. Parasitol. 94: 1118-1127.

YANG W., LiN Y. 1994: [Two new species of Acanthobothrium cestodes (Tetraphyllidea: Onchobothriidae) from saltwater fishes in Xiamen, South Fujian, China.] J. Xiamen Univ., 33: 532-536. (In Chinese.)

Cite this article as: Maleki L., Malek M., Palm H.W. 2015: Four new species of Acanthobothrium van Benden, 1850 (Cestoda: Onchoproteocephalidea) from the guitarfish, Rhynchobatus cf. djiddensis (Elasmobranchii: Rhynchobatidae), from the Persian Gulf and Gulf of Oman. Folia Parasitol. 62: 012. 